\title{
Mining and the Environment in Melanesia: \\ Contemporary Debates Reviewed
}

Glenn Banks

C

ontroversies linked with the large-scale mines in Melanesia largely revolve around the environmental impact of their waste management strategies on the communities living downstream of the mine. Sites such as Ok Tedi, Bougainville, and Freeport have become emblematic labels for the environmental excesses of large-scale mining corporations in the region generally. They have generated lawsuits, corporate soul-searching, and, in the case of Bougainville, armed rebellion. In this paper I focus on three of these mines, and argue for a reframing of these disputes.

First, I sketch the broader argument as it applies in various forms across all the individual operations. Many observers continue to frame the issues associated with these mines as solely "environmental" or "ecological" problems. David Hyndman and Stuart Kirsch, for example, argue that the Ok Tedi mine has created an environmental problem, and they frame community responses to this "ecological crisis" as "ecological resistance."

In less than a decade, weak environmental protection plans, coupled with a long series of ecological disasters associated with the mine, had endangered the environment of thirty thousand indigenous peoples downstream of the mine.

The ecological crisis resulting from the Ok Tedi mine was and continues to be centered on the Yonggom, the indigenous landowners of the lower Ok Tedi. Their intimate association of myth, belief and environment has been irrevocably broken. Motivated by environmental degradation, Yonggom political leaders eventually succeeded in forging a popular ecological resistance movement. (Hyndman 200I, 33-34; emphasis added)

Both Kirsch and Hyndman have been scathing of attempts by others, myself included, to suggest that there may be other social, cultural, or economic factors involved in local protests against these mines. Kirsch, for example, wrote that "many observers persist in attributing the origins of

The Contemporary Pacific, Volume I4, Number I, Spring 2002, 39-67

(C) 2002 by University of Hawai'i Press 
the [Ok Tedi] lawsuit to economic motives" and that these same observers "suggested that localconcerns about pollution were not significant because they did not appear in the form in which they were expected" (I997, I 28, I29). Hyndman, in writing the moral high ground for himself, goes further (200I, 40), denouncing "economic-based models" of mine-induced social conflict propagated by observers such as Colin Filer (I990), David King (1997), Chris Ballard (1997), and Richard Jackson (1998) for ignoring the "popular ecological resistance" movements that the mines generate.

In his review of existing explanations of conflicts generated by largescale mining, Kirsch is critical of the fact that the environmental impact of the mines plays a limited role (I997, I I9-I 2I). Yet his analysis provides little in terms of an alternative model, simply falling back on an explanation of conflict grounded in "ecological crisis," and offers few insights into the varied ways in which communities in Melanesia have responded to the intrusions of mining multinationals into their territories. I argue that while the environmental rhetoric used by Kirsch and Hyndman accounts in large part for why these mining practices have attracted the attention and criticism of nongovernmental organizations and publics in countries such as Australia and the United States, a strict environmental view of the conflict misses much of the intent of indigenous responses to the mines.

This is not to say that the mines do not create environmental effectsindeed there is widespread devastation of large areas of forest, land, and gardens in areas around and downstream of some of them, an aspect covered in detail later. However, to fully understand the responses of the peoples affected, it is necessary to distinguish between the impacts on the physical environment and the broader effects of the mines on people's lives - in other words, to look beyond a discourse on ecological crisis. Such an alternative view would place the responses in their broader social, cultural, political, environmental, and economic contexts (see Johnston 1994), and when this is done community reactions and initiatives can be viewed as being fundamentally concerned with control over resources. In many cases the control sought is expressed in terms of relationships (and particularly in regard to potential or unrequited reciprocity; Kirsch I996a), grounding the disputes squarely in a fundamental aspect of social relations within the region.

A more robust and widely applicable framework than the "ecological crisis" proposed by Kirsch would look at the way in which control over a range of resources is affected by the mining operations. Resources in this 
context are those material or socially constructed elements that communities employ to construct, maintain, and transform their physical, social, and cultural lifeworlds. This approach parallels the growing literature in which political ecologists are increasingly incorporating the notion of environment into a framework of human livelihood (eg, Bryant and Bailey I997).

Such a definition has two consequences. First, it allows the incorporation of both subsistence resources derived directly from the natural environment and other material resources such as cash crops and wages. Second, other socially and culturally constructed resources can be incorporated into such a definition. These can include political resources at both local and supralocal levels; social resources such as relationships and systems of rights and responsibilities within a community; and cultural attachments to land, place, and local landscapes and environments. Place and landscape can be infused with locally specific meaning, and serve a number of aesthetic, utilitarian, spiritual or other roles for individuals and communities. An emphasis on the interrelationship between the "real" and the constructed nature of these resources highlights the way in which control over resources is rarely simple or stable. Incorporation of communities into wider spheres of influence, for example, can easily see a local group lose political control over its own future (Hyndman 1995), although it is also possible to see the reverse process at work, as I discuss further later.

In part this debate becomes one of semantics. The use of the terms ecological and environmental has a particular resonance in developed countries, of an environment and ecology separate from society (Adams I990). To understand community responses to mining in Melanesia requires dropping these essentially Eurocentric divisions between the environment and the rest of one's daily life. These communities do not make the same distinctions between environmental and other resources: their environmental consciousness, as anthropologists frequently point out, is more holistic, and fuses the social, cultural, political, economic, and environmental aspects of landscapes in a way that does not occur in the developed world.

In other words, instead of portraying this as a debate between environmental and economic explanations of conflicts as Kirsch did- "There may well be people living in Papua New Guinea who are willing to trade a few feet of mud in their gardens and a few acres of dead trees for a winning lottery ticket" (I997, I30)—westerners need to recognize that for 
these communities the environmental is economic, and it is also social and political life and cultural sustenance. The framework put forward here allows for the possibility that some communities may indeed, as Kirsch put it, be prepared to trade "a few feet of mud" for other forms of material resources or "development." Further, it allows for recognition that the environmental impacts of the mines on these communities have themselves created the conditions that enable them to tap into political, legal, and media resources in the international sphere (Kirsch I996b, I996c). ${ }^{1}$ In this sense community complaints over environmental issues may be symptomatic of wider problems. When such problems are framed as "environmental" or "ecological" issues, the people affected, their lawyers, and authors such as Hyndman and Kirsch are able to tap into a strong international vein of environmental rhetoric that is more readily accepted and so more likely to attract support in the developed world than a discourse of community development and livelihoods.

A final note of clarification relates to the use of the term community. I use it largely unproblematically throughout the paper, but acknowledge that concepts such as "community control" over resources of any kind are not straightforward or without severe, potentially damaging complications. In Melanesia the term community is riddled with contradictions, hierarchies, exclusions, and power relations and, like landowner (Filer I997), has acquired significant political and popular weight in the region. For the purposes of the debate over the impacts of mines, however, these definitional issues are secondary. What is meant here by "community control" over resources is for control to reside locally with members of those groups who have traditionally exercised such control.

Having introduced the argument, I now sketch the regional context of the industry and introduce the various mines in the region, concentrating on the three that I then discuss further-the Porgera, Ok Tedi, and Freeport mines.

\section{The Mines and Their Impact in Outline}

The mining industry is now a central part of the economies, environments, and societies of countries of the region. The formal economy of Papua New Guinea, for example, is dominated by the mining and oil sector, which has made up approximately 70 percent of exports and accounted for 25 percent of gross domestic product for the bulk of the last three decades (Connell I997). Although new exploration has slowed, a number 


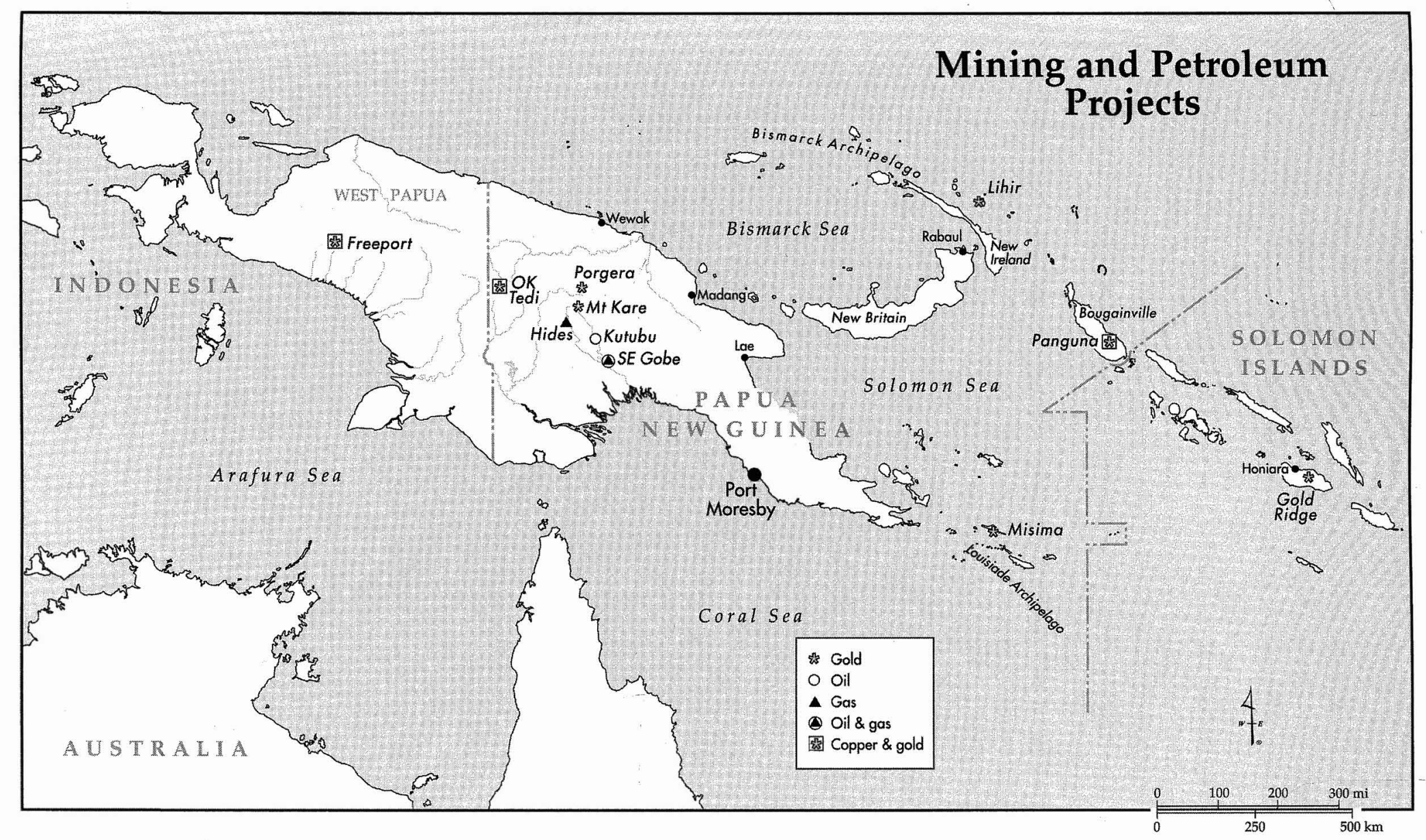

MAP I. Mining and petroleum projects in New Guinea and Solomon Islands. 
of large-scale projects are likely to come on line in the next few decades, the timing depending more on global commodity markets than on domestic factors. The major mines are spread throughout the region, as shown in map $\mathrm{I}$.

The Ok Tedi mine, operated by Ok Tedi Mining, is a large-scale copper and gold mine in the Western Province of Papua New Guinea. Since the late I980s it has been the focus of a dispute over its impact on the Ok Tedi and Fly River systems. The dispute originated in 1984, when efforts to secure the tailings ${ }^{2}$ from the mine were abandoned following the collapse of the site of the proposed tailings dam. Tailings have been discharged directly to the river system for the last fifteen years. A lawsuit in Australia against Broken Hill Proprietary (ВНР), the majority shareholder in the operation, was led by Yonggom landowners from the lower Ok Tedi region, and ran from 1994 to 1996 (Banks and Ballard 1997). The out-ofcourt settlement involved various compensation packages and a commitment by Broken Hill Proprietary to implement a feasible tailings containment option as soon as practicable (Banks and Ballard I997, appendix I; BHP I999, I3). In mid-I999 however, the company announced that none of the options being considered (including immediate closure) would provide a marked improvement in the downstream environmental situation (Firth 1999). It is now expected that some 900 square kilometers of tropical lowland forest will be progressively inundated over the next ten years, regardless of which option is selected, and a worst-case scenario could see an area of I,350 square kilometers affected by dieback (BHP I999, I4-I5; Sproull I999).

The PT Freeport Indonesia Grasberg mine in West Papua (map I) is now the world's largest copper and gold mine, and in 2000 was the world's single largest producer of gold-2.3 million ounces (Freeport-McMoRan 200I). It has a thirty-year history of conflict with the local Amungme people, who live in the highlands area around the mine, and its environmental impact on the Aikwa River downstream (the traditional lands of the Kamoro people) has also been the subject of international condemnation and action by nongovernmental organizations (Bryce 1996; Kennedy I997). In terms of its area of environmental impact, the euphemistically labeled Aikwa Deposition Area in the lowlands is an area of about I 20 square kilometers comprising dead trees and thick tailings sludge. Less obvious, but also of concern, is the impact of the mine operation and supporting infrastructure (including large camps, towns, and waste dumps) on the highland environment, located adjacent to the Lorentz National 
Park, and within the traditional lands of the Amungme people. The mine is majority owned and operated by Freeport-McMoRan Copper and Gold, a New Orleans-based company, with minority shareholding from Rio Tinto and Indonesian interests.

The Porgera mine is a relatively high-grade gold mine, which in 1992 was the world's third largest gold producer, and the largest outside South Africa. In 2000 the mine produced over 900,000 ounces of gold, making it the largest gold producer in Papua New Guinea and Australia (CNW 200I). Placer Dome, a Canadian mining multinational, is the major ( 50 percent) shareholder and operator of the mine, which began operations in 1990. The Porgera mine is better known outside Papua New Guinea as “another Ok Tedi” (Kennedy I996a) because, like Ok Tedi's, its tailings are discharged into a river system and, again like Ok Tedi, it has been the subject of attention from Australian and international nongovernment organizations, particularly environmental ones. Unlike Ok Tedi and Freeport, concerns over the environmental effects of the Porgera mine are due less to the deposition of tailings and sediment downstream-which has been largely absent in the Porgera case-and more to do with possible chemical effects and associated claims of deaths.

These three mines are the central focus of the paper, although similar issues have arisen at the Lihir gold mine in Papua New Guinea (a large, newer gold mine that uses "deep ocean disposal" of its tailings), the Gold Ridge gold mine in Solomon Islands (a relatively small gold mine that has some tailings retention, but continues to dump waste rock in the headwaters of a river system), and the proposed Ramu nickel mine in Madang Province in Papua New Guinea. Most controversially similar environmental concerns occurred in the context of the Panguna copper mine owned and operated by Bougainville Copper in Papua New Guinea (map I), which was closed by local protests in 1989. Environmental damage to the Jaba River from mine tailings was an important element of the community opposition to the mine (AGA 1989; Hughes and Sullivan I992), although as other commentators have pointed out, there were a multitude of other factors at work (eg, Filer I990, I992; Griffin I990; Wesley-Smith I990; Wesley-Smith and Ogan I992). The mine closure sparked a ten-year civil war, the resolution of which is still slowly and hesitantly being worked out (Wesley-Smith I999).

To sum up, the various mine operations generate similar environmental issues: 
- Tailings disposal is problematic in all cases. In environments with high rainfall, steep terrain, and often weak geomorphic structures, the mining companies argue that containment of tailings at the mine site (a common practice in Australia and the United States) is not feasible.

- Riverine disposal of these tailings therefore occurs in all cases except Lihir, Misima, and Ramu Nickel, where deep ocean disposal of the tailings occurs (or is planned for Ramu).

- A final issue that becomes important to the argument is that in each of the three main cases, as well as Bougainville, the communities living downstream from the mine were not included in discussions or negotiations before the construction of the mine and its subsequent impact on their environment.

There are also significant differences between the mines in terms of their impact on the environment and the communities living downstream:

- The amount of tailings being deposited varies markedly between Porgera (I 8,000 tons per day), Bougainville and Ok Tedi (80,000 tons per day), and Freeport (currently over 220,000 tons per day and intending to rise to near 300,000 tons per day).

- The riverine environments that receive these tailings and other waste rock are also significantly different, a factor that is critical because the eventual deposition of the tailings and other waste rock is dependent on both the discharge of the river and the profile of the riverbed. Between them, these factors determine how far the different material is carried and, eventually, how much material is deposited where. To briefly illustrate one aspect of this, figure I shows the profiles of the rivers that carry tailings from the Bougainville, Freeport, Ok Tedi, and Porgera mines. In both Bougainville and Freeport, the mines are located relatively close to the coast, and, because both of these rivers have comparatively low discharges, the effects of tailings are felt intensely in a relatively small area. At Ok Tedi, the nature of the profile is such that while the most dramatic effects are felt where the Ok Tedi River enters the lowland plain, they continue to be felt throughout the entire length of the Fly River system, diluted somewhat by its much greater discharge.

- The population in the areas downstream from the mines varies for each operation. In the large Ok Tedi-Fly River catchment area downstream of Ok Tedi, thirty thousand people signed up for the lawsuit 
against Ok Tedi (Kirsch 1997; Gordon 1997). In the other cases, as I discuss later, more modest numbers are involved.

Having sketched the regional context of the industry, I now focus on three of the mines-Porgera, Ok Tedi, and Freeport - and look in detail at how debates about the environmental impacts of the mines have been played out.

\section{Porgera}

The Porgera mine first came to international attention in 1994-1995 when there were national and international reports of deaths in areas downstream of the mine (Shearman I995; Kennedy I996a). The response of the mining company to these accounts, by nongovernment organizations and local communities, was to call in a team from the Commonwealth Scientific and Industrial Research Organisation (CSIRO), the Australian government's scientific research arm. Their report largely exonerated the company from any association with deaths or serious impacts on the environment (CSIRO I996).

The ways in which community responses to this environmental issue varied down the river system were striking. According to the CsIRO report the impact of the tailings on the river system also varied markedly through-

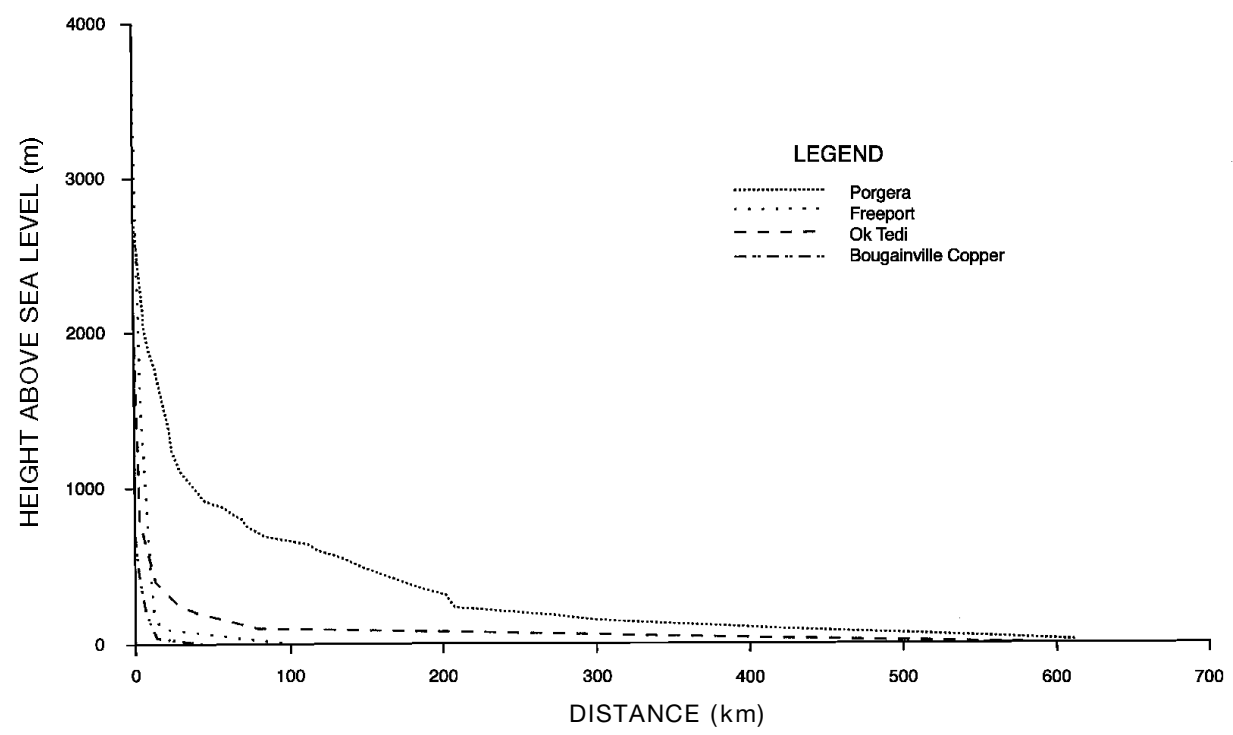

FiguRE I. Riverine profiles for large mines in New Guinea and Solomon Islands. 
out the Porgera-Lagaip-Strickland river system, but the community responses did not correspond in any clear way with the environmental impacts in each area. The impacts and the responses can be divided broadly in to three main zones along the river system.

The first of these zones is the Porgera River itself, which is approximately 50 kilometers in total length. In this area the environmental impact is most profound, and most obvious. Tailings and waste rock from the mine have covered much of the upper river system to a depth of several meters. The river, with a modest discharge, now carries very high sediment loads, to the extent that the limited biodiversity present before the mine existed is now gone. In the valley is a large population (of perhaps 6,000 people) with customary rights to the river (Ipara 1994). Their major concern has been their loss of access to a valued resource: the alluvial gold they previously panned in the river was their primary source of income prior to the opening of the mine (Filer 1999). Mine wastes covered the alluvial gold, leading to community protests, which in turn led to riots, and a local activist was elected to the national parliament on a popular "fair compensation" platform in the 1997 national elections. Eventually, relatively large and ongoing compensation payments were made by the company to the traditional owners (Banks I998).

In an interesting twist to this story, where the mine tailings spew out the end of a pipe, local landowners have been panning them for the gold that the sophisticated mine processing facility failed to capture. The panners, using the most primitive technology, often make more from gold extracted from the tailings than their clansmen who are employed by the mine. Significantly, there have not been public claims of deaths and sickness from this group, who spend their days knee-deep in pure mine tailings. On the two occasions that I spoke to some of the two hundred people involved in this activity, their major concerns were economic - the likely fate of world gold prices and the local price of mercury. Even though they were subject to massive environmental effects, were in constant contact with the tailings, and used very unsafe mining practices, such as the use of mercury to concentrate and extract the gold, community concerns were being expressed in economic rather than environmental or health terms. A discourse on environmental crisis alone can not account for such a community response.

The second "impact zone" covers the 200-kilometer length of the Lagaip and middle Strickland rivers. In this zone the effects of the tailings are much diluted, but some reduction in biodiversity has occurred because of 
the effects of increased sediment loads (CSIRO I996). There appears to be very limited potential for chemical effects within this zone because the river is still fast flowing and dropping relatively steeply. A limited population lives in the immediate area, with an estimated four hundred people living within Io kilometers on either side (Shearman I995, 30) and larger populations who visit and use the area irregularly. This area has been the focus of national and international attention as reports of deaths (up to 600 at last report) from local communities have been picked up and publicized by national and international nongovernment organizations (see Kennedy I996b, for example). Reductions in fish numbers, diseased fish, and the death of birds and animals that came into contact with the waters were also reported. The cultural significance of the Strickland Gorge to the Duna people who live in this area has been highlighted, with one author from a nongovernment organization reporting that "the intense transformation of their spiritual landscape is itself a cause for members of traditional communities such as the Duna and Hewa to have suffered unusual illness and death" (Kennedy I996a, 24).

The final zone is the 300-kilometer-long, winding, lower Strickland River. In this portion of the river, where its slow-moving waters become more acidic, the CSIRO report found a potential risk of metal mobilization from the tailings that may affect the health of fish and sago, although it stressed that there was no evidence of this occurring to date (1996). This area also has a small population (400) living close to the river along its length (Shearman I995, 30). These people are more dependent on the resources of the river (fish and sago) and use it for transport. The area has attracted little attention, although there are some reports of a massive reduction in fishing (though not necessarily of fish) for some of the communities. Lake Murray, a large freshwater lake adjacent to the lower Strickland and a recipient during floods of sediment (and hence tailings) from the Strickland is regarded by the company and the state as the environment where the potential long-term risks of mercury concentration in the food chain are the highest. Here the company has supported a somewhat sporadic local commercial fishing industry. In a symbolic rather than scientific display of confidence in the mine's environmental impact, fish are purchased by the company and served in the mess at Porgera to mine management and employees.

In summary, the greatest level of national and international concern over the environmental effects of the tailings is focused on the area that has neither the largest population, nor the greatest environmental risk. 
How can this be explained? To begin, it must be noted that the middle Strickland region, like many parts of rural Papua New Guinea, is struggling to move beyond what Howlett twenty-five years ago called a "terminal phase of development" (I973). Opportunities for earning cash are few (Stürzenhofecker I998). Government services have steadily declined in quality and quantity over the past fifteen years. Where there were once eleven aid posts along the Lagaip and Strickland rivers, now there are three, and even these suffer from a continual shortage of drugs (Haley and Robinson 1996). The area is becoming increasingly marginalized in terms of contact with outside institutions. This marginalization has been increasing in relative as well as absolute terms for the Duna, who, while experiencing the mine's negative impact on a river that is very significant to them culturally, and to a lesser extent, economically (in subsistence terms), have observed from the sidelines as their Porgeran Ipili neighbors gained enormous wealth as a result of its operation. Perhaps most galling for the Duna, they had no control over these processes: they were not consulted or even informed of the changes prior to their occurrence.

Along with their increasing marginality, the pre-European-contact worldview of the Duna is still deeply implicated in the community's understanding of current processes. Two anthropologists recently pointed to research in the area carried out in the early I970s in which Duna explained how, without regular ritual performances, the ground would dry out and lose its fertility, the rivers would run red, and the world would end (Haley and Robinson 1996). During the first few years of operation Porgera's tailings were a deep red. Given the paramount place of visual messages in these societies, it is no wonder that many Duna believed this was another sign that the world would end (see also Haley I996a).

While this research provides insights into why Duna protests may have occurred, it does not explain the claims of widespread deaths, accepting for the moment the finding of the CSIRO report (1996) that there was little or no possibility of the mine's pollution being responsible for any chemical effects in this region. ${ }^{3}$ Nicole Haley offered one possibility, noting that the English word pollution has entered the local vernacular, with people being told by visiting nongovernment organizations that it meant "olsem poison" (the same as poison; I996b). Poison in the local setting glosses a range of unexplained deaths, sorcery, and witchcraft. As a result people in the area, on hearing that the company was polluting the river, understood that "the river is deadly and the PJV is killing people," and as a 
result "all deaths in the riverine corridor are being attributed to pollution, [with] deaths previously attributed to other causes . . . now being reinterpreted and reconsidered" (Haley I996b). Chris Ballard reported a similar process connected with the I997-I998 El Niño-induced drought in Irian Jaya (2000a). The very real fear in the communities and their lack of knowledge of or control over the changes initiated by the mine could help to account for the claims of deaths in the area.

Finally, it is worth noting that, as a strategy, the protests of the Duna and the Hewa people in the Strickland area have been successful. Company assistance to these communities has increased dramatically in the last four years, and the Strickland communities (and not the Porgera landowners) have two representatives, along with their own selected scientific advisers, on a new body (the Porgera Environmental Advisory Komiti, or PEAK) that was put in place to review the company's follow-up on the recommendations made by the CSIRO report and generally monitor the downstream environmental performance of the Porgera Joint Venture. In this sense the marginality of the Duna has declined somewhat, and a relationship with the mining company has been established.

This discussion suggests strongly that the issue of the environmental impact of the Porgera mine was, from the local perspective, about issues of marginality and involvement in decision-making, about control (or lack of it) over resources (environmental, political, cultural, and economic), and about the direction of change in people's lives. It was not simply or solely an argument over environmental impact, quality, or aesthetics, and could not be reduced to such.

\section{Ok Tedi}

In Australia and internationally, the Ok Tedi mine has come to be associated with downstream environmental problems created by tailings disposal, although as Jackson pointed out (I993) it should also be considered a financial disaster for most of those involved, particularly Broken Hill Proprietary and the other shareholders (including the state of Papua New Guinea). The media and Australian church and nongovernmental groups, including the Australian Conservation Foundation, have focused on the effects of the deposition of tailings in the lower Ok Tedi River. There is no doubt that these have been profound. Extensive areas of riverbank gardens and rainforest are now smothered by the layers of tailings deposited when the slow-flowing river floods over its banks. 
[The waste] has been deposited onto forest and garden land, into adjacent wetland areas and upstream into the numerous creeks and streams that flow into the Ok Tedi .... The mine wastes have had adverse impact wherever they have been deposited, killing plants and trees, and disrupting local ecosystems. The damage extends for forty kilometres or so along the river, with areas of dead trees that extend up side creeks up to three kilometres from the main channel. (Kirsch I993, 29)

Clearly, the physical environment has been significantly affected by these mine wastes. The latest "predictions" from Broken Hill Proprietary expect that, regardless of what happens in terms of the mining operation over the next ten years (the anticipated life of the mine), the extent of the damage will increase dramatically (B HP I999, I4-16).

But is this just an environmental problem for the communities involved? Several different lines of evidence suggest that framing Ok Tedi solely as an environmental issue is not recognizing the nature of the problem as experienced by the communities involved.

First, Kirsch's richly detailed and evocative transcriptions of interviews with Yonggom clearly point to a perspective of the issue that is fundamentally about loss of cultural and economic resources. For example, he quoted Bumok Dumanop, a woman from Dome village in the lower Ok Tedi: "I'm unhappy with what the company has done. They have spoiled our way of life. Before we lived easily: food from the gardens was plentiful, as was wild game. The river was fine: you could see the fish, the turtles and all the other animals living there. But now it is gone and it's hard. We're suffering, so I'm unhappy about that" (cited in Kirsch I997, I23).

These people have lost access to garden land along the fertile river flood plain, which has been covered by mine wastes. Now they must compete for plots in the rain forest that produce one or two harvests at most. There are fewer fish in the Ok Tedi and most people are afraid to eat them. Few turtles come up the Ok Tedi to lay their eggs: formerly this was an important seasonal resource. Many of the small creeks and streams that feed into the Ok Tedi are choked with mine waste; it has become difficult to catch prawns and crayfish. Some sago trees along the river have died; other trees in adjacent wetlands are threatened. Still other sago stands have been swallowed by the widening Ok Tedi. The forest fringing the river was also once a rich hunting ground for animals that came to the river to drink. (Kirsch 1993, 29)

Kirsch and local landowners such as Alex Maun (I997) went on to record other issues the Yonggom faced as a result of the tailings: dangers in using 
the now faster-flowing river for transport, lack of fish in the river, loss of freshwater supplies, and a drastic change in their landscape (Kirsch 200I). In addition, the forest and garden resources of people in these communities were under further pressure due to the presence of several thousand West Papuan refugees in camps in the area, a point that Kirsch noted when he wrote tellingly that local resource pressures are a result of "the destructive synergism on local resources between refugee consumption of resources and the environmental impact of the mine" (I997, I40 n 6). The distinction that Kirsch made here, between the impact on local resources due to the refugees and the impact on the environment because of the mine, is a key one for his argument, and one that I believe needs to be rethought.

The same distinction is not as clear in the words of Yonggom themselves. A 1988 petition from Dome village, for example, raised four issues of concern: a lack of government development in the area, the pollution of the Ok Tedi and Fly Rivers (where the impact on subsistence and cash resources was highlighted), a lack of compensation for these losses, and the impact of the refugees (who were "destroying the rest of our environment”) (Banks and Ballard I997, appendix 2). Identical language is used for the impact of the mine pollution and the refugees: the former had "spoiled" fish, prawns, riverbank gardens, and crocodiles, and the latter had likewise "spoiled" other subsistence resources including lands for hunting, fishing grounds, and sago swamps.

I argue, then, that these are best viewed as resource issues, and specifically as a conflict over the control of resources. It is clear that the subsistence resource base, as well as the cultural and social resources that derive from the local environment, and even the resources that Yonggom used to raise cash, were destroyed or threatened by the tailings. In this way the additional impacts of refugees impinge further on the local communities' security over their resources, environment, and local landscape. ${ }^{4}$ To provide a framework that allows for the incorporation of all threats to resource abundance and control does not mean that all threats need be regarded equally: clearly the source of the major damage to Yonggom resources, and their control over resources, has been the Ok Tedi mine and its tailings disposal. Kirsch also noted the constant complaint of villagers concerning the lack of communication between the mine and the villages, and hence the marginalization of Yonggom from decision-making over issues that affected their resources (I993).

The accounts by anthropologists who worked with the Wopkaimin peo- 
ple living around the mine site at Ok Tedi again point to the contextual importance of the environment in these debates. In many respects they have suffered as much, if not more, environmental damage as the Yonggom-they have lost over Io percent of their territory, including an entire mountain that used to be regarded as "sitting on top of the land of the dead" (Hyndman I995, 78). Despite this, the Wopkaimin were not involved in the lawsuit at all, and Hyndman himself noted a lack of environmental protest by the Wopkaimin due to them having "always enjoyed monetary compensation not received by other indigenous people downstream" (200I, 33). The resources framework proposed here would note that the environmental damage and the associated loss of land (a critical cultural, environmental, and subsistence resource for the Wopkaimin) has been offset by the substantial material resources the Wopkaimin have secured from the mine, including new housing and substantial sums of money through wages, royalties, dividends, compensation, and business developments in Tabubil (Jackson 1993). ${ }^{5}$ Wopkaimin, then, had a relationship with Ok Tedi Mining that the Yonggom did not, and whether or not it was an equal relationship, or even whether the Wopkaimin had a great degree of choice in establishing this relationship (the evidence is that they had little; see Hyndman I995), it is a situation where a livelihood or resource-based framework accounts for the indigenous response much better than a simple environmental focus.

A final example drawn from Ok Tedi is the case of the Awin people, who are the neighbors of the Yonggom, living on the eastern side of the Ok Tedi river. Their land was affected as much by the mine tailings as was that of the Yonggom, but they were, by and large, not as interested in pursuing and prosecuting the lawsuit. It appears that much of the difference in the approaches of the two groups could be explained by the fact that the Awin use of the Ok Tedi river as an environmental and subsistence resource was much diminished in recent times as they had moved closer to the KiungaTabubil road (see Burton 1993; King 1997). As a result they had been able to gain access to greater monetary resources than the still relatively isolated Yonggom. The political and economic context of the two groups, and their respective access to and control over both economic and environmental resources, could then account for why their responses to essentially the same environmental impact have been so different.

The broader Ok Tedi situation presents plenty of evidence that, from the local perspective, the varying responses to the presence of the mine are 
not related in any simple way to its environmental impact. It appears, fundamentally, that the access and control that the different communities had over a range of resources-economic as well as environmental, political, social, and cultural-played a major role in shaping their responses to the mine. The Yonggom response was different from those of the Awin and the Wopkaimin because the Yonggom had lost massive areas of gardens and rainforest to the mine waste, without any involvement in the decisions that led to this result, and had not gained any benefits in exchange for this loss. The situated nature of this response is underlined by the terms of the settlement of the lawsuit. The settlement, negotiated on behalf of the Yonggom and other plaintiffs, provided for both a moderation of the environmental impacts (by securing agreement from Broken Hill Proprietary to implement a feasible tailings containment option as soon as practicable) as well as a compensation package including cash, community infrastructure, and trust funds (Banks and Ballard I997, appendix I). Effectively, the settlement fundamentally reshaped the relationship between the Yonggom and the mine.

\section{Freeport}

The environmental effects of Freeport are on a scale that could potentially at least rival Ok Tedi's, simply because the total volume of tailings being released over the next thirty to forty years by the mine will dwarf that of Ok Tedi. Although the current management strategy is to contain these tailings within the I2O-square-kilometer area described earlier, it is not clear that this is a viable long-term solution (Minewatch 1996). Environmental aspects of the operation have been the focus of many local and international protests and actions against the mine. Two of the most highprofile ones were a lawsuit lodged in the US courts by an Amungme landowner and the cancellation of the company's political risk insurance in 1995. The lawsuit was concerned with issues of human rights and "cultural genocide," and the environmental effects on both the immediate mine area and the downstream environs. The damage was said to include "deforestation of rain forest and the contamination of the region's surface and ground water through ore leachate." These "violations of international environmental law" were claimed to be "tantamount to acts of ecoterrorism" (Beanal $v$ Freeport-McMoRan I996).

The environmental effects of the mine also led, in I995, to the cancellation of political risk insurance coverage by the Overseas Private Invest- 
ment Corporation, which concluded that the effects of the tailings "posed an unreasonable or major environmental, health or safety hazard" (OPIC 1995). Although after arbitration the insurance was reinstated (and a year later dropped by Freeport) and the environmental aspects of the lawsuit were dismissed early in the proceedings, both the lawsuit and the OPIC decision have continued to brand Freeport as an environmentally destructive mine.

Despite the clear evidence of massive environmental damage, a program of work carried out between 1994 and 1998, in which I was involved, that focused on documenting the history and contemporary situations of the Kamoro and the Amungme peoples - the traditional landowners of the area within PT Freeport's Contract of Work area-found that other issues dominated local concerns (UABS I998a). This wide-ranging study, a collaborative project funded by Freeport and involving personnel from the Australian National University, Universitas Cenderawasih in Jayapura, Freeport, and the local communities, worked under the direction of the Kamoro and Amungme communities and covered topics of concern to them. It involved fieldwork in each of the main indigenous villages in the contract area, including village surveys, household interviews, and extensive meetings and interviews with local representatives and a range of other interested parties: churches, local government officers, Freeport officials, other researchers, and consultants. One of the key, if somewhat obvious, findings of relevance here was that the environmental effects of the mine varied throughout the impact area, with a distinct split between the effects on the traditional lands of the highland Amungme and the lowland Kamoro.

The direct impact of the mine on the lands and environment of the Amungme has been large, with a river carrying tailings running alongside what is now one of the larger villages, and roads and pipelines dissecting the lower Amungme valleys. The largest components of the mine infrastructure (towns, mines, mill complexes, and waste dumps) are away from the village environment, but are in areas of particular cultural significance that are still used for hunting. In terms of the total physical area affected, and alongside both the Ok Tedi situation and the lowland Kamoro communities, the environmental effects in the Amungme territory are not as widespread. As in the case of the Yonggom and the Duna, though, a lack of community involvement over decision-making in relation to this impact is again evident, and a central community concern is the lack of regard and 
acknowledgment for the Amungme as the original owners of this territory. The most significant concern for the Amungme coming out of the study was their subjection, over three decades, to human rights abuses by Indonesian military, with the implicit cooperation if not direct involvement of the Freeport company (see Ballard 2002).

In recent years this military presence has increased dramatically, to the point where the contract area is now one of the most heavily militarized zones in Indonesia (Ballard 2000b, 25). This militarization is, ostensibly at least, to protect the mine from local insecurity, although internal clashes between different elements of the military and the pursuit of commercial interests by various military units have led to greater insecurity in the region for all parties, including Freeport. Despite the internal bickering and increasing political problems that the military presence has created, it is clearly the local indigenous communities that have suffered most from the military presence, with a series of massacres of Amungme recorded between I994 and I996, and ongoing abuses subsequently (ACFOA I995; Ballard 2000b, 2002). For this reason, while environmental issues were not absent from Amungme agendas, recognition of their human rights and their status as the traditional landowners by the company dominated their concerns, despite the environmental focus and language of the lawsuit mentioned earlier (UABS I998b).

Among the lowland Kamoro, whose land is used for the tailings retention area and various components of the mine infrastructure (including a town site, airport, and port), the environmental impacts are much more obvious than among the Amungme. However, protests by the Kamoro about the environmental effects have been muted, particularly in comparison to those of the Amungme. One example, which again illustrates the resource-based concern of local environmental perspectives, was a letter sent by a group of Kamoro to PT Freeport Indonesia in early I997 protesting plans to extend the tailings deposition area. In this letter, in which the Kamoro are described as "victims of toxic chemical waste and environmental damage" caused by the mine, the three reasons for the protest are listed as: the likely destruction of the last remaining area of ancestral tribal lands for this group; the importance of this area for harvesting sago, wood for canoes, plants for traditional medicine, and of the river for fishing; and the impact of existing tailings on the sago palms and trees, the animals, and plants used for traditional medicine (Negeripi and Nawaripi peoples I997). 
On the basis of the UABS work in the major Kamoro contract villages, it became clear that the central issue to Kamoro was control over (or rather lack of control over) resources, particularly land. Comparing the different situations among the Kamoro villages, the team argued that "the extent to which the various Kamoro communities have been relocated or moved from their original land appears to be central to their current social and economic situation" (UABS I998c, 48). While for some of the communities relocation had been forced due to the environmental impacts of the mine, for others, relocation had been voluntary, or for reasons that had little to do with environmental issues. The difference that loss of access to local land made in terms of control over resources (economic as well as political and cultural) was clearly illustrated by the case of two neighboring Kamoro communities in the contract area, neither of which experienced a direct environmental impact from the tailings (both were located in the river system neighboring the Aikwa River).

One (Hiripau) was located on land over which the community had traditionally exercised rights and still had ready access to subsistence and other resources. They also had significantly higher education participation rates, higher incomes, less reliance on store-bought foods, greater household assets, and a greater sense of community cohesion and direction. The other (Paumako) was located on land that they traditionally did not have rights to, and exhibited a much less cohesive sense of community, with lower incomes but, perversely, a higher dependence on purchased foodstuffs, and widespread alcohol abuse in the community. This second community had been relocated by the government and the company to its current site from an area adjacent to the mine's port facility, and thus had no control over the resources or the land around them. Consequently subsistence (and commercial) production was difficult for them. Environmental effects did not lead to the relatively poor situation of the second village; the key factor was loss of control over a whole suite of resources (environmental, cultural, and economic).

To sum up the Freeport case, again the evidence indicates no direct link between the extent of environmental damage and the nature and extent of community protest. Rather, expanding the scope of the argument to include issues of community control over a wide range of resources permits drawing in Amungme protests about their loss of autonomy over cultural and subsistence resources (particularly land), as well as their human rights, and similar Kamoro concerns with their loss of control over subsistence resources (again, particularly land). The UABS work suggested 
that "eco-terrorism" is not the whole picture: rather the focus of the communities was pitched more broadly at community control (or lack of it) over their resources (environmental, social, economic, and cultural) and their future.

\section{The Debates Reframed}

To what extent are these environmental conflicts? In one sense Hyndman and Kirsch are right. The mines do have effects on the environment, and the effects have been devastating in places, something that everyone, even - belatedly-Broken Hill Proprietary, agrees. There is also a degree of agreement between both sides of the debate over the extent to which the problems at their root are about community involvement in the decisionmaking that affects them, their resources, and their environments. But do the effects on the environment mean that the resulting community impacts should be glossed solely as environmental problems? Clearly, as the examples used here have illustrated, similar environmental problems have generated very different responses from different communities. There are cases such as the Yonggom, where the environmental effects of the mine are the overwhelming concern because of the massive impact on the community's resource base. But in other cases, marginalization, overt oppression, or access to new forms of resources (material or political) has resulted in different actions and reactions by communities. One can make sense of these different responses through a framework that emphasizes resource control and livelihoods, not one that focuses only on "environmental crises" or ecological impacts.

As noted earlier, in some senses this is a debate over semantics: the use by Kirsch and Hyndman of the terms environmental and ecological resonates with Eurocentric baggage - of an environment that is external to, and separate from, people's daily lives - and hence is too limiting to encompass an indigenous perspective of the problems and changes these communities face. If we continue to frame these conflicts as environmental in the sense in which the word is commonly used in the west, it becomes an environment divorced from the rich web of social, economic, and cultural meanings and importance.

The debate, though, is also more than just semantics. It also has implications for the resolution of these conflicts. Kirsch has warned that not emphasizing the environmental gives the mining industry an easy out, "absolv[ing] the mine of its fundamental responsibility for its environ- 
mental impact" ( 1997, I30). Do solutions to the existing problems lie in environmental fixes? In part, clearly yes. By reducing their impact on the environment, and hence the pressures they place on the social, cultural, and economic resources and livelihoods of the communities around and downstream of them, the miners can reduce the conflict they experience with these communities.

It can also be argued, though, that a large part of the problem at Ok Tedi arose because of just such a distinction between the environmental issues and the social, cultural, and economic context in which they occurred. Broadly, the focus of the mine's environmental monitoring was in the downstream areas, including the lower Ok Tedi (and Yonggom people), while community and business development efforts were initially directed along the road between Tabubil and Kiunga (Awin), and in the immediate mine area (Wopkaimin) (Jackson I993). In this sense, the Yonggom were only included in Ok Tedi Mining's frame of reference as part of the environment. If a broader understanding of the social, economic, political, cultural, and environmental context of the area had been central to the mine's planning and operation, then many of the problems faced by the Yonggom (and many of Ok Tedi Mining and Broken Hill Proprietary's later problems) might have been avoided.

To give another example, if riverine disposal of tailings were to stop at Porgera, the Duna would still be a marginal community along the river, faced with increasing disparity and inequity with their Porgera neighbors. An environmental fix would resolve a series of community concerns over use and abuse of the river system as a resource, but it would not address other concerns over regional relationships, resource control, and equity. Likewise at Freeport, a focus solely on the environmental dimensions of the mine detracts from the issues of concern to the communities-human rights and community control over resources, particularly land. Technological fixes (which obviously involve no community input) if anything encourage a retreat from dealings with the downstream communities. ${ }^{6} \mathrm{~A}$ focus on environmental issues in this sense could marginalize these communities, and in effect work against the call of Papua New Guinea's National Research Institute for "development that puts people at the centre, not the periphery" 7 (cited in Connell I997, 27I).

While acknowledging the paramount importance for the downstream communities of the effects of mine waste on their resource base, the argument made here leads to the conclusion that for mining companies to consider only the environmental aspects of their operation, ignoring the cul- 
tural, economic, political, and social realities of resource use and control in the areas in which they operate, also provides those companies with another "easy out." 8 Miners (and other resource extractors) must be made aware of, and be made to respond to, the social, economic, cultural, political, and environmental contexts in which they operate.

THIS PAPER WAS WRITTEN while I was a visiting fellow at the Research Program, East-West Center, Honolulu. An earlier version was presented at a seminar jointly organized by the Center for Pacific Islands Studies, University of Hawai' $i$ and the East-West Center. Thanks to the participants of that seminar and to Chris Ballard, Allen Clark, Donald Denoon, Sitiveni Halapua, Flip van Helden, Dan Jorgensen, Eugene Ogan, Kim Small, and Terence Wesley-Smith for useful comment, conversations, and feedback. Stuart Kirsch has been a stimulating interlocutor on the issues that this paper is concerned with. Of course none of those mentioned is responsible for the views expressed here. The map was prepared by Keith Mitchell of the cartography section of the Research School of Pacific and Asian Studies, Australian National University, and the figure by Ian McCredie of the School of Geography and Oceanography, University College, University of New South Wales.

\section{Notes}

I This echoes the work by Gelder and Jacobs on the role of the "sacred" in contemporary Aboriginal Australian discourse and politics (I998, 5I). They argue in part that the structures and fact of dispossession, disturbing and horrendous though they are, have themselves now created spaces for new forms of political voice and authority for Aboriginal people.

2 Tailings are the very fine, ground up rock left over as a result of processing, often containing trace heavy metals such as, in the case of copper mines, residual copper, or in the case of gold mines, cyanide used in the processing.

3 As a caution to privileging this scientific knowledge, it is worth noting the report's concern with Porgera Joint Venture's generally poor understanding of the river system and its dynamics.

4 Recent reports from Western Province illustrate that local concerns with the presence of the refugees continue to be strong (Kakarere 2000).

5 David Hyndman wrote of the Wopkaimin as being "ecologically rich, economically poor," again differentiating between subsistence and cash economic resources (I995, I). More detailed and recent data than those used by Hyndman clearly indicate that the Wopkaimin are now, by Papua New Guinea standards 
and more generally, economically wealthy (Jackson I993), something that Hyndman has belatedly acknowledged (200I, 33).

6 As one reviewer noted, there is a danger in promoting the notion that if corporations did have a broader view of the communities they were affecting, they would be willing and able to do something about it. Burton, among others, has demonstrated that this is often patently not the case (1995). Here the argument is rather that "the environment" as a distinct and separate entity is something that the mining corporations are prepared to spend vast amounts of money on monitoring and debating with their critics. This, in large part, is because they are able to apply a technocratic and scientific approach to this "external" environment, an approach that very poorly accommodates community issues.

7 See also the call by Overton for notions of sustainable development that include ecological, economic, and social dimensions-not one or two at the exclusion of the others (1999).

8 Interestingly, and perhaps worryingly given the argument presented here, this is the stance that Broken Hill Proprietary appears to be taking in terms of the Ok Tedi experience, with senior management now openly talking about Ok Tedi as "not compatible with our environmental values" (in Firth 1999).

\section{References}

ACFOA, Australian Council for Overseas Aid

I995 Trouble at Freeport: Eyewitness Accounts of West Papuan Resistance to the Freeport-McMoRan Mine in Irian Jaya, Indonesia and Indonesian Military Repression, June I994-February I995. Canberra: ACFOA. Adams, William

I990 Green Development: Environment and Sustainability in the Third World. London: Routledge.

AGA, Applied Geology Associates

I989 Environmental, Socio-Economic and Public Health Review: Bougainville Copper Mine. Review for National Executive Council of Papua New Guinea. Wellington: AGA.

Ballard, Chris

I997 It's the Land Stupid! The Moral Economy of Resource Ownership in Papua New Guinea. In The Governance of Common Property in the Pacific Region, edited by Peter Larmour, 47-65. Pacific Policy Paper I9, National Centre for Development Studies. Canberra: Australian National University.

2000a Condemned to Repeat History? ENSo-Related Drought and Famines in Irian Jaya, Indonesia, 1997-98. In El Niño: History and Crisis, edited by Richard Grove and John Chappell, I23-I48. Cambridge: White Horse Press. 
200ob Competing Interests at the Freeport Mine in Irian Jaya. IIAS Newsletter 22 (June): 25. Leiden, 3-4 times a year. Website: www.iias.nl

2002 The Signature of Terror: Violence, Memory and Landscape at Freeport. In Inscribed Landscapes: Marking and Making Place, edited by Bruno David and Meredith Wilson, 29-5 I. Honolulu: University of Hawai'i Press. In press.

Banks, Glenn

I998 Compensation for Communities Affected by Mining and Oil Developments in Melanesia. The Malaysian Journal of Tropical Geography 29 (I): $53-67$.

Banks, Glenn, and Chris Ballard, editors

I997 The Ok Tedi Settlement: Issues, Outcomes and Implications. Pacific Policy Paper 27. Canberra: National Centre for Development Studies and Resource Management in Asia Pacific project, Australian National University.

Beanal $v$ Freeport-McMoRan Inc and Freeport-McMoRan Copper and Gold Inc I996 Suit filed in United States District Court, Civil Action Case 96-I474, Section: SECT.K Mag.3. Available online at http://www.moles.org/ ProjectUnderground/motherlode/freeport/lawsuit.html

в HP, Broken Hill Proprietary

I999 BHP and Ok Tedi: Discussion Paper. August. Melbourne: BнP.

Bryant, Raymond L, and Sinéad Bailey

I997 Third World Political Ecology. London: Routledge.

Bryce, Robert

I996 Spinning Gold. Mother Jones. September-October I996. Available online at http://www.motherjones.com/mother_jones/SO96/bryce.html

Burton, John

I993 Development in the North Fly and Ningerum-Awin Area Study. OkFly Social Monitoring Programme Report 6. Port Moresby: Unisearch PNG Proprietary for Ok Tedi Mining.

I996 What Is Best Practice? Social Issues and the Culture of the Corporation in Papua New Guinea. In Conference Proceedings: Mining and Mineral Resource Policy Issues in Asia-Pacific. Prospects for the 2 Ist Century, edited by D Denoon, C Ballard, G Banks, and P Hancock, I29-I34. Canberra: Research School of Pacific and Asian Studies, Australian National University.

CNW, Canada NewsWire

200I Placer Dome Reports Record Cash Flow and Mine Operating Earnings. Canada NewsWire, I5 February.

Connell, John

I997 Papua New Guinea: The Struggle for Development. London: Routledge. 
CSIRo, Commonwealth Scientific and Industrial Research Organisation

I996 Review of Riverine Impacts: Porgera Joint Venture. Canberra: CSIRO Environmental Projects Office.

Filer, Colin

I990 The Bougainville Rebellion, the Mining Industry and the Process of Social Disintegration in Papua New Guinea. Canberra Anthropology I3 (I): I-39.

I992 The Escalation of Disintegration and the Reinvention of Authority. In The Bougainville Crisis: I99I Update, edited by M Spriggs and D Denoon, I I 2-I 45. Canberra and Bathurst: Research School of Pacific Studies, Australian National University in Association with Crawford House.

I997 Compensation, Rent and Power. In Compensation for Resource Development in Papua New Guinea, edited by Susan Toft, I 56-I89. Port Moresby and Canberra: Papua New Guinea Law Reform Commission and National Centre for Development Studies, Australian National University.

Filer, Colin, editor

1999 Dilemmas of Development: The Social and Economic Impact of the Porgera Gold Mine, 1989-I994. Pacific Policy Paper 34. Canberra and Port Moresby: Asia Pacific Press, Resource Management in Asia Pacific, and National Research Institute.

Firth, D

I999 It's Official: Ok Tedi Is a Disaster. Australian. Melbourne. I2 August. Freeport-McMoRan

$200 \mathrm{I}$ Fourth-quarter and Twelve-months Results. News release. FreeportMcMoRan Copper and Gold, New Orleans.

Gelder, Ken, and Jane Jacobs

I998 Uncanny Australia: Sacredness and Identity in a Postcolonial Nation. Melbourne: Melbourne University Press.

Gordon, John

I997 The Ok Tedi Lawsuit in Retrospect. In Banks and Ballard, I4I-I66. Griffin, James

I990 Bougainville Is a Special Case. In The Bougainville Crisis, edited by Ron May and Matthew Spriggs, I-I 5. Bathurst, NSw: Crawford House Press.

Haley, Nicole

I996a Revisioning the Past, Remembering the Future: Duna Accounts of the World's End. Oceania 66 (4): 278-285.

I996b When Pigs Fly: Pigs, Pollution and Porgera. Paper given in Resource Management in Asia-Pacific Seminar Series, Research School of Pacific Studies, Australian National University. November. 
Haley, Nicole, and Rebecca Robinson

I996 A Preliminary Study of the Social Impacts of the Porgera Gold Mine on Downstream Communities in the Lagaip and Upper Strickland River Areas. Report to the Porgera Joint Venture.

Howlett, Diana

I973 Terminal Development: From Tribalism to Peasantry. In The Pacific in Transition, edited by H C Brookfield, 249-273. London: Edward Arnold.

Hughes, Philip, and Marjorie Sullivan

1992 The Environmental Effects of Mining and Petroleum Production in Papua New Guinea. Port Moresby: University of Papua New Guinea. Hyndman, David

1995 Ancestral Rainforests and the Mountain of Gold: Indigenous Peoples and Mining in New Guinea. Boulder, co: Westview Press.

$200 \mathrm{I}$ Academic Responsibilities and Representation of the Ok Tedi Crisis in Postcolonial Papua New Guinea. The Contemporary Pacific I3 (I): $33-54$.

Ipara, Kurubu

I994 Lower Porgera Land Investigation Report. Report to Porgera Joint Venture. November.

Jackson, Richard

I993 Cracked Pot or Copper-Bottomed Investment: The Development of the Ok Tedi Project I982-I991, a Personal View. Townsville: Melanesian Studies Centre, James Cook University.

I998 Review Article: David and Goliath on the Fly. Journal of Pacific History 33 (3): 307-3II.

Johnston, B R, editor

I994 Who Pays the Price? The Sociocultural Context of Environmental Crisis. Washington, DC: Island Press.

Kakarere, Ian

2000 Papua New Guinean Shot Dead in West Papua. Independent, I3 December.

Kennedy, Danny

I996a Ok Tedi All Over Again: Placer and the Porgera Gold Mine. Multinational Monitor March, 22-24.

I996b Porgera: Arsenic and Gold. Mining Monitor I (2): 7-8.

I997 Freeport Follies. Project Underground Newsletter. July.

King, David

I997 The Big Polluter and the Constructing of Ok Tedi: Eco-imperialism and Underdevelopment along the Ok Tedi and Fly Rivers of Papua New Guinea. In Banks and Ballard, 94-I I 2. 
Kirsch, Stuart

1993 The Yonggom People of the Ok Tedi and Moian Census Divisions: An Area Study. Ok-Fly Social Monitoring Programme Report 5. South Hadley and Port Moresby: Unisearch PNG Proprietary for Ok Tedi Mining.

I996a Refugees and Representation: Politics, Critical Discourse and Ethnography along the New Guinea Border. In Mainstream(s) and Margins: Cultural Politics in the 9os, edited by M Morgan and S Leggett, 222-236. Westport, ст: Greenwood Press.

I996b Acting Globally: Eco-politics in Papua New Guinea. Journal of the International Institute (University of Michigan) 3 (3): I.

I996c Anthropologists and Global Alliances: Comment. Anthropology Today I 2 (4): I 4-I6.

I997 Is Ok Tedi a Precedent? Implications of the Lawsuit. In Banks and Ballard, I I 8-i 40.

$200 \mathrm{I}$ Changing Views of Place and Time along the Ok Tedi. In From Myth to Minerals: Mining and Indigenous Lifeworlds in Australia and Papua New Guinea, edited by J Weiner and A Rumsey. Bathurst: Crawford Press.

Maun, Alex

I997 The Impact of the Ok Tedi Mine on the Yonggom People. In Banks and Ballard, II3-II7.

Minewatch

I996 Minewatch report on Dames and Moore audit. Available online at http://www.moles.org/ProjectUnderground/motherlode/freeport/ minewatch.html

Negeripi and Nawaripi Peoples

I997 Protest against environmental destruction and rejection of plans to move people from their tribal lands. Letter to PT Freeport Indonesia, Jakarta, 25 January.

OPIC, Overseas Private Investment Corporation

I995 OPIC Policy of Contractors and Exporters Insurance C592. Letter to Freeport-McMoRan Copper and Gold. New Orleans, 3I October.

Overton, John, editor

I999 Strategies for Sustainable Development: Perspectives from the Pacific. Sydney: University of New South Wales Press.

Shearman, Philip

I995 The Environmental and Social Impact of the Porgera Gold Mine on the Strickland River System. BSc (Honors) thesis, Department of Geography and Environmental Studies, University of Tasmania.

Sproull, R

I999 Ok Tedi Challenge for Anderson. Australian, 2 August. 
Stürzenhofecker, Gabriel

1998 Times Enmeshed: Gender, Space, and History among the Duna of Papua New Guinea. Stanford, C A: Stanford University Press.

UAB 5 , Universitas Cenderawasih-Australian National University Baseline Study I998a Final Report: General Report. UABs Report 6. Canberra and Jayapura, for PT Freeport Indonesia.

I998b Final Report: Amungme Baseline Study. UABs Report 8. Canberra and Jayapura, for PT Freeport Indonesia.

I998c Final Report: Kamoro Baseline Study. UABs Report 7. Canberra and Jayapura, for PT Freeport Indonesia.

Wesley-Smith, Terence

I990 The Politics of Access: Mining Companies, the State, and Landowners in Papua New Guinea. Political Science 42 (2): I-I9.

I999 Papua New Guinea. The Contemporary Pacific I I (2): 438-443.

Wesley-Smith, Terence, and Eugene Ogan

I992 Copper, Class, and Crisis: Changing Relations of Production in Bougainville. The Contemporary Pacific 4 (2): 245-267.

\section{Abstract}

Recent controversies linked with the large-scale mines in Melanesia largely revolve around the impact of their waste management strategies on downstream communities. This issue has generated debate and conflict at Ok Tedi and Porgera in Papua New Guinea, PT Freeport Indonesia's Grasberg mine in Irian Jaya, and Ross Mining's Gold Ridge mine in the Solomon Islands. In each case, the issue is generally portrayed as purely an environmental one. There is evidence, though, that from the indigenous perspective the range of issues involved extends beyond the environmental to take in economic, social, political, and cultural concerns. In this paper, I revisit debates about the links between the environment and economic development in the context of mining in Melanesia. I suggest that the distinction between environmental and other causes of these disputes is overstated in relation to Melanesian communities. Instead, I argue that disputes over the impacts of the mines are better understood as disputes over community control of resources, and hence control over the direction of their lives.

KEYWORDS: environment, Melanesia, mining, resource control, socioeconomic context 